\title{
Detection and characterisation of haplosporidian parasites of the blue mussel Mytilus edulis, including description of the novel parasite Minchinia mytili n. sp.
}

\author{
Georgia M. Ward ${ }^{1,2,3, *}$, Stephen W. Feist ${ }^{2}$, Patricia Noguera ${ }^{4}$, Mar Marcos-López ${ }^{4,5}$, \\ Stuart Ross ${ }^{2}$, Matthew Green ${ }^{2}$, Ander Urrutia ${ }^{2}$, John P. Bignell ${ }^{2}$, David Bass ${ }^{1,2}$ \\ ${ }^{1}$ Department of Life Sciences, Natural History Museum, London SW7 5BD, UK \\ ${ }^{2}$ Centre for the Environment, Fisheries and Aquaculture Sciences (Cefas), Weymouth DT4 8UB, UK \\ ${ }^{3}$ College of Life and Environmental Sciences, University of Exeter, Exeter EX4 4QD, UK \\ ${ }^{4}$ Marine Scotland Science, Aberdeen AB11 9DB, UK \\ ${ }^{5}$ FishVet Group Ireland, Oranmore, County Galway, Ireland
}

\begin{abstract}
The edible mussel Mytilus edulis is a major aquaculture commodity in Europe, with $168000 \mathrm{t}$ produced in 2015. A number of abundant, well characterised parasites of the species are known, though none are considered to cause significant mortality. Haplosporida (Rhizaria, Endomyxa) is an order of protistan parasites of aquatic invertebrates, the best studied of which are the oyster pathogens Haplosporidium nelsoni and Bonamia ostreae. While these species are well characterised within their hosts, the diversity, life-cycle and modes of transmission of haplosporidians are very poorly understood. Haplosporidian parasites have previously been reported from Mytilus spp., however the majority of these remain uncharacterised, and no molecular data exist for any species. In this study, we identified 2 novel haplosporidian parasites of $M$. edulis present in the UK. The first of these, observed by light microscopy and in situ hybridisation infecting the gills, mantle, gonadal tubules and digestive connective tissues of mussels in the Tamar estuary, England, we describe as Minchinia mytili on the basis of $18 \mathrm{~S}$ sequence data. The second, observed infecting a single archive specimen collected in Loch Spelve, Mull, Scotland, infects the foot muscle, gills and connective tissue of the digestive gland. Sequence data places this parasite in an uncharacterised clade of sequences amplified from tropical bivalve guts and water samples, sister to $H$. nelsoni. Screening of water and sediment samples collected at the sample site in the Tamar estuary revealed the presence of both sequence types in the water column, suggesting host-free or planktonic life stages.
\end{abstract}

KEY WORDS: Ascetosporea · Haplosporida - Haplosporidium - Minchinia · Mussel · Mytilus · Parasite

\section{INTRODUCTION}

The blue mussel Mytilus edulis Linneaus, 1798 is of immense significance to aquaculture worldwide, with over 190000 t produced globally in 2015 (FAO 2017). The majority of these mussels were farmed in

\footnotetext{
*Corresponding author: georgia.ward@nhm.ac.uk
}

Europe (168000 t), with France (61000 t), the Netherlands $(54000 \mathrm{t})$ and the UK $(20000 \mathrm{t})$ being the largest producers. Outside of Europe, the Atlantic coast of Canada is also a major producer $(22000 \mathrm{t}$ in 2015). In addition to the value of this species to global aquaculture, as filter feeders, mussels play an impor-

(C) The authors 2019. Open Access under Creative Commons by Attribution Licence. Use, distribution and reproduction are unrestricted. Authors and original publication must be credited. 
tant role ecologically, filtering waterborne nutrients and particles, and their sessile lifestyle makes them ideal proxies for the detection of local environmental contaminants such as heavy metals and organic chemicals, as demonstrated by the United States' NOAA Mussel Watch program (Kimbrough et al. 2008).

Continued interest in the economic exploitation of mussels for aquaculture has led to a number of attempts to establish baselines for population health, aiming in particular to shed light on the parasites and pathogens of the species, their significance and distribution (e.g. Figueras et al. 1991, Bignell et al. 2008). Such studies predominantly utilize histopathological methods and have identified several highly prevalent, widely distributed parasites, including the copepod Mytilicola intestinalis and the gill ciliate Ancistrum mytili. Both of these are ubiquitous in Mytilus spp. populations across Europe, and though they can be linked to a loss of condition, they are not thought to be associated with increased mortality in the host (Villalba et al. 1997). More recently, studies of baseline population health have incorporated molecular screening of mussel tissues for specific parasite groups, allowing for the more sensitive detection of rarer, low-prevalence parasitic infections (e.g. Lynch et al. 2014).

Over recent decades, the protistan class Ascetosporea (Rhizaria, Endomyxa) has emerged as an important group of parasites of economically significant aquatic species. Ascetosporea is comprised of 5 orders, the most well known of which is the Haplosporida, which includes species known to infect molluscs, crustaceans and annelid worms in both marine and freshwater environments. The orders Mikrocytida, Paramyxida and Paradinida also include important invertebrate pathogens, though their diversity and host range are only very recently becoming apparent (Hartikainen et al. 2014b, Ward et al. 2016, 2018). The fifth order, Claustrosporida, remains very poorly characterised, comprising just 2 described species, Claustrosporidium gammari and $C$. asellii, with no molecular data available for either species (Larsson 1987, Cavalier-Smith \& Chao 2003).

Haplosporida includes over 40 described species across 4 genera (Haplosporidium, Minchinia, Bonamia and Urosporidium) and a number of undescribed species (Arzul \& Carnegie 2015). In addition, recent haplosporidian-targeted molecular studies using group-specific primer sets to probe environmental water and sediment (Hartikainen et al. 2014a) and bivalve gut samples (Pagenkopp-Lohan et al. 2016) have revealed significant uncharacterised molecular diversity within the order.

The most well-studied haplosporidian species are the oyster parasites Haplosporidium nelsoni and Bonamia ostreae, responsible for mass mortalities in Crassostrea spp. and Ostrea edulis respectively (Ford \& Haskin 1982, Robert et al. 1991). Economic losses associated with $B$. ostreae infection are so significant that the parasite is currently listed as notifiable to the World Organisation for Animal Health (OIE) (http://oie.int/en/international-standard-setting/ aquatic-code 2017).

Urosporidium spp. parasitise free-living annelid worms and Platyhelminthes, themselves parasites of marine molluscs and crustaceans. Minchinia spp. have been reported only from marine molluscs (Ford et al. 2009), and Bonamia spp. from oysters (Engelsma et al. 2014). The most speciose genus, Haplosporidium, is comprised of species parasitising molluscs, crustaceans and annelid worms in both marine and freshwater environments (Arzul \& Carnegie 2015).

The morphology of haplosporidian spores has frequently been used to assign species to genera, with species belonging to the 'microcell' genus Bonamia previously presumed not to form spores (Perkins 2000). Haplosporida form ovoid, walled spores without polar filaments or tubules, with an orifice at one pole. Urosporidium spp. produce unornamented spores with an internal flap composed of spore wall material covering the orifice. In Minchinia and Haplosporidium spp., the orifice is covered by an external hinged lid. Both genera form ornamented spores, though differ in the origin of this ornamentation: in Minchinia spp., ornamental extensions are formed of epispore cytoplasm, while the extensions of Haplosporidium spp. spores are composed of spore wall material (Burreson \& Ford 2004). All Urosporidium and Minchinia species for which the spore structure is known are concordant with these criteria, but the only species of Bonamia known to form spores, $B$. perspora, produces spores matching the criteria for Haplosporidium (Carnegie et al. 2006). Further, lineages with the 'haplo' spore structure do not form a monophyletic clade (Burreson \& Reece 2006; supported by more recent analyses by Hartikainen et al. 2014a, Pagenkopp-Lohan et al. 2016) and are therefore unsuitable for defining Bonamia and Haplosporidium; even more so when the necessary taxonomic revisions have been made to Haplosporidium. It is likely that more genera must be created in order to resolve the paraphyletic Haplosporidium. However, with spore structure and molecular data cur- 
rently lacking for the type species, H. scolopli, it remains unclear which clade should be considered the true Haplosporidium (Arzul \& Carnegie 2015).

The life-cycles of haplosporidian parasites are also largely unknown, though evidence exists to suggest direct transmission between hosts in at least some non spore-forming Bonamia species, including $B$. ostreae (Engelsma et al. 2014). Numerous unsuccessful attempts have been made at direct transmission of $H$. nelsoni, and so the involvement of intermediate hosts in the parasite life-cycle is suspected, though none have been identified (Powell et al. 1999). The presence of a large diversity of haplosporidian sequence types in the water column and sediment may suggest either free-living transmissible stages or the involvement of planktonic metazoans in haplosporidian life-cycles (Hartikainen et al. 2014a).

Haplosporidians have been reported in Mytilus spp. mussels on numerous occasions, however only 2 have ever been formally described: $H$. tumefacientis, causing distinctive tumour-like lesions in the kidney and digestive tissues of $M$ californiensis in California, USA (Taylor 1966), and H. mytilovum, infecting the ovocytes of $M$. edulis, which was later reassigned to the microsporidian genus Steinhausia following microscopic examination of fresh material (Sprague 1972). More recently, haplosporidians have been observed infecting Mytilus spp. in Maine, USA (Figueras et al. 1991), southern France (Comps \& Tigé 1997) and the Atlantic coast of Canada (Stephenson \& McGladdery 2002). However, insufficient morphological data were available in each case to formally describe any of these parasites, and no molecular data exists for any haplosporidian parasite of Mytilus.

This study combined traditional histopathological light microscopy with targeted, group-specific environmental and host-focused molecular probing and in situ hybridisation (ISH) to characterise a novel haplosporidian parasite infecting M. edulis in Devon, England, UK. A further novel haplosporidian is informally described from a single archive specimen of M. edulis from the west coast of Scotland.

\section{MATERIALS AND METHODS}

\subsection{Sample collection}

A total of 156 Mytilus edulis were collected from the River Tamar estuary mouth near Cremyll Ferry, Devon, UK, in June 2013 and incubated overnight (Hartikainen et al. 2014b) in sterile artificial seawater
(Culture Collection of Algae and Protozoa recipe) in batches of 10, clustered according to sampling proximity. Transverse sections to include the digestive gland, gonad, gills and mantle were then fixed in Davidson's solution for histological processing and examination, $2.5 \%$ glutaraldehyde for transmission electron microscopy (TEM) and 100\% moleculargrade ethanol for molecular analyses, as in Ward et al. (2016). Subsequent processing for microscopy and DNA extraction were as described in Ward et al. (2016). Water samples were collected from 3 sites in the Tamar estuary (Cremyll Ferry, Wilcove and Neal Point), processed and DNA extracted as in Ward et al. (2016). A further $153 \mathrm{M}$. edulis were collected from the same site in July 2013 and tissues fixed for microscopy as above. Digestive gland and mantle tissues were preserved in RNALater (Qiagen) for molecular analyses, as in Ward et al. (2016).

Forty $M$. edulis were collected from a farmed population in Loch Spelve, Mull, Scotland, UK, as part of an investigation into reported mortalities in January 2011. DNA was extracted from formalin-fixed material from a single specimen in which haplosporidian plasmodia had been observed during histology screening using the EZNA FFPE DNA extraction kit with the kit's standard xylene deparaffinisation protocol (Omega Biotek).

\subsection{PCR and sequencing}

All PCR reactions were performed in $20 \mu \mathrm{l}$ volumes consisting of $1 \times$ Promega colourless buffer, $2.5 \mathrm{mM}$ $\mathrm{MgCl}_{2}, 0.4 \mathrm{mM}$ dNTPs, $0.5 \mu \mathrm{M}$ of each primer, $0.2 \mathrm{mg}$ bovine serum albumin (BSA), 0.5 U GoTaq G2 (Promega) and $1 \mu \mathrm{l}$ template DNA. The sequences of all primers used in this study are shown in Table 1. DNA extracted from $M$. edulis tissues from the Tamar estuary was screened using the nested, haplosporidianspecific primer set of Hartikainen et al. (2014a), targeting the V7-V9 variable regions of the 18S rRNA gene. Resultant amplicons were visualised on $2 \%$ agarose gels stained with GelRed (Biotium) and Sanger sequenced unidirectionally using primer V5fHapl.

The 2 distinct haplosporidian sequence types (Type 1 and Type 2) amplified from these tissues were aligned with all known haplosporidian sequence types using the MAFFT e-ins-I algorithm (Katoh \& Standley 2013). This alignment was used to design specific primer sets for each sequence type to be used for lineage-specific PCR screening of incubation and eDNA samples and for the gen- 
Table 1. Sequences of primers used in this study for group- and species-specific haplosporidian probing and 18S sequence extension. Reference indicates original publication of primer sequences; where none is provided, primers were designed for this study

\begin{tabular}{|c|c|c|c|}
\hline Primer name & Primer sequence $\left(5^{\prime}-3^{\prime}\right)$ & Purpose & Reference \\
\hline $\begin{array}{l}\text { C5fHap } \\
\text { Sb1n }\end{array}$ & $\begin{array}{l}\text { GTA GTC CCA RCY ATA AAC BAT GTC } \\
\text { GAT CCH TCY GCA GGT TCA CCT ACG }\end{array}$ & $\begin{array}{l}\text { General haplosporidian } 18 \text { S nested } \\
\text { PCR first round }\end{array}$ & $\begin{array}{l}\text { Hartikainen et } \\
\text { al. (2014a) }\end{array}$ \\
\hline $\begin{array}{l}\text { V5fHapl } \\
\text { Sb2nHap }\end{array}$ & $\begin{array}{l}\text { GGA CTC RGG GGG AAG TAT GCT } \\
\text { CCT TGT TAC GAC TTB TYC TTC CTC }\end{array}$ & $\begin{array}{l}\text { General haplosporidian } 18 \mathrm{~S} \text { nested } \\
\text { PCR second round }\end{array}$ & $\begin{array}{l}\text { Hartikainen et } \\
\text { al. (2014a) }\end{array}$ \\
\hline $\begin{array}{l}\text { Hap-M258f } \\
\text { Hap-M412r }\end{array}$ & $\begin{array}{l}\text { AAC TTT TAG CGT CCA GCC CA } \\
\text { CGA GGT TGC CAA GTT CTT TCG }\end{array}$ & $\begin{array}{l}\text { Minchinia mytili-specific tissue and } \\
\text { environmental PCR screens and } \\
\text { in situ hybridisation probe generation }\end{array}$ & \\
\hline $\begin{array}{l}\text { Hap-E312f } \\
\text { Hap-E620r }\end{array}$ & $\begin{array}{l}\text { CAT AGC AGA TGG AAG TTT GAG G } \\
\text { GGA GCC AAA TCC GAG GAC TT }\end{array}$ & $\begin{array}{l}\text { Haplosporidium sp.-specific tissue and } \\
\text { environmental PCR screens and in situ } \\
\text { hybridisation probe generation }\end{array}$ & \\
\hline Hap-E449r & TTG GAT GCA CTT TCA AGA TTA CC & $\begin{array}{l}\text { Haplosporidium sp.-specific } 18 \mathrm{~S} \text { reverse } \\
\text { primer used for SSU sequence extension }\end{array}$ & \\
\hline $\begin{array}{l}\text { HapGenFor33 } \\
\text { HapGenFor84 }\end{array}$ & $\begin{array}{l}\text { TTG YCT YAA AGA TTA AGC CAT GCA } \\
\text { CTG TGA AAC TGC AKA TGG CTC }\end{array}$ & $\begin{array}{l}\text { General haplosporidian 18S forward } \\
\text { primer for SSU sequence extension }\end{array}$ & \\
\hline
\end{tabular}

eration of ISH probes. The specificity of each primer set was tested by screening a panel of tissues infected with other haplosporidian species (Bonamia ostreae, Haplosporidium nelsoni, $H$. edule, $H$. littoralis, $H$. costale and Minchinia mercenariae) and uninfected, PCR-negative host DNA samples. In each case, an amplicon was produced only from templates known to be the intended lineage, as confirmed by Sanger sequencing. The first round general haplosporidian primer set of Hartikainen et al. (2014a), C5fHap and Sb1n, was used for the first round for both lineage-specific PCRs. PCR probing for Type 1 used primers Hap-M258f and Hap-M412r and the following cycling conditions: $5 \mathrm{~min}$ denaturation at $95^{\circ} \mathrm{C}$, followed by 30 cycles of $95^{\circ} \mathrm{C}$ for $1 \mathrm{~min}$, annealing at $63^{\circ} \mathrm{C}$ for $1 \mathrm{~min}$ and extension at $72^{\circ} \mathrm{C}$ for $1 \mathrm{~min}$. Amplicons were extended by final incubation at $72^{\circ} \mathrm{C}$ for $10 \mathrm{~min}$ and stored at $4^{\circ} \mathrm{C}$. Screens for Type 2 used primers Hap-E312f and Hap-E620r and the same conditions as for Type 1, but with an annealing temperature of $64^{\circ} \mathrm{C}$. The single haplosporidianinfected $M$. edulis collected from Loch Spelve, Scotland, was screened using the Type 1 and Type 2 primer sets individually as a single-round PCR only (i.e. no nesting). Mussels collected in the Tamar estuary were screened once more by PCR separately using only Type 1 and Type 2 lineagespecific primers (i.e. not nested) to give an approximation of prevalence of molecular signal.

Prior to phylogenetic analysis, both haplosporidian SSU sequence types were extended by PCR to include the V2-V7 variable regions. To extend
Type 1, first round PCR used primers HapGenFor33 and Hap-M412r, followed by a second round using primers HapGenFor84 and Hap-M412r. For Type 2, first round PCR used primers HapGenFor33 and Hap-E620r, followed by a second round using HapGenFor84 and Hap-E449r. All 4 PCRs used the following cycling conditions: $5 \mathrm{~min}$ denaturation at $95^{\circ} \mathrm{C}$, followed by 40 cycles of $95^{\circ} \mathrm{C}$ for $30 \mathrm{~s}$, annealing at $55^{\circ} \mathrm{C}$ for $1 \mathrm{~min}$ and extension at $72^{\circ} \mathrm{C}$ for $90 \mathrm{~s}$. Amplicons were extended by final incubation at $72^{\circ} \mathrm{C}$ for $12 \mathrm{~min}$ and stored at $4^{\circ} \mathrm{C}$. Amplicons were then visualised on a $1.5 \%$ agarose-TAE gel stained with GelRed, and bidirectionally sequenced using second-round primers. Low-quality base calls were removed before consensus sequences were formed from these reads and initial V7-V9 amplicons.

\subsection{Phylogenetic analysis}

All available full-length haplosporidian 18S sequence types and those covering the V5-V9 variable regions were downloaded from NCBI GenBank in August 2017. Sequences not overlapping this region or without significant (>200 bp) sequence overlap were excluded from analyses. BLASTn searches of haplosporidian sequences against the GenBank database were used to identify uncharacterised (including environmental) sequences related to known taxa. The extended haplosporidian sequence types generated in this study were aligned with these using MAFFT ver- 
sion 7, e-ins-I algorithm (Katoh \& Standley 2013). The resulting alignment, using the closest known haplosporidian relatives ENDO-3 (Bass et al. 2009) as an outgroup, was refined by eye and analysed in RAxML BlackBox v.8 (Stamatakis et al. 2008, Stamatakis 2014) (GTR model with CAT approximation; all parameters estimated from the data). A Bayesian consensus tree was constructed using MrBayes v.3.2.5 (Ronquist et al. 2012). Two separate $\mathrm{MC}^{3}$ runs with randomly generated starting trees were carried out for 2 million generations each with 1 cold and 3 heated chains. The evolutionary model applied a GTR substitution matrix, a 4 category autocorrelated gamma correction and the covarion model. All parameters were estimated from the data. The trees were sampled every 1000 generations and the first 500000 generations discarded as burn-in (trees sampled before the likelihood plots reached stationarity). A consensus tree was constructed from the remaining sample.

\subsection{Histology and in situ hybridisation (ISH)}

M. edulis tissues were preserved, prepared for histology and screened for pathogens using light microscopy as in Ward et al. (2016). Haplosporidian Type 1-specific probes for ISH were generated by PCR using a sample previously PCR-positive for this sequence type in which haplosporidian plasmodia were visible in histology as template DNA. Type 2specific probes used a PCR-positive M. edulis sample as a DNA template, though no plasmodia were readily visible in the tissue under light microscopy. Probes were labeled using digoxigenin(DIG)-11dUTP in reactions of $100 \mu \mathrm{l}$ volume with a final concentration of $1 \times$ Promega colourless buffer, $2.5 \mathrm{mM}$ $\mathrm{MgCl}_{2}, 20 \mu \mathrm{M}$ PCR DIG labeling mix (Roche), $5 \mathrm{U}$ of Promega GoTaq G2 polymerase, $6 \mu$ l of template DNA and $0.5 \mu \mathrm{M}$ each of primers Hap-M258f and Hap-M412r (Type 1) or Hap-E312f and Hap-E620r (Type 2). Cycling conditions were as detailed in Section 2.2 for lineage-specific PCR. Tissue sections $4 \mu \mathrm{m}$ thick were mounted onto Poly-L lysine slides, de-paraffinised by immersion in Clearene (Leica Biosystems), rehydrated and treated with Proteinase $\mathrm{K}$ solution $\left(45 \mu \mathrm{g} \mathrm{ml}^{-1}\right)$ for $20 \mathrm{~min}$ at $37^{\circ} \mathrm{C}$ in a humid chamber. Proteolysis was terminated by incubation in distilled water and slides rinsed in ice-cold $12 \%$ acetic acid for $45 \mathrm{~s}, 70 \%$ industrial methylated spirits (IMS) for $3 \mathrm{~min}, 100 \%$ for $3 \mathrm{~min}$ and $2 \times$ saline sodium citrate (SSC) buffer for 1 min with agitation. Sections were overlaid with hybridisation solution $(4 \times$ SSC buffer, $50 \%$ formamide, $1 \times$ Denhardt's solution, $10 \%$ dextran sulphate, $250 \mathrm{\mu g} \mathrm{ml}^{-1}$ salmon sperm DNA) containing $10 \mathrm{ng}^{-1}$ probe (negative controls lacked the DIG-labelled probe in the hybridisation buffer). Slides were heated to $94^{\circ} \mathrm{C}$ for $7 \mathrm{~min}$ and hybridised overnight at $47^{\circ} \mathrm{C}$. After hybridisation, sections were washed in room temperature washing buffer $(6 \mathrm{M}$ urea, $0.5 \times \mathrm{SSC}$ and $\left.20 \mu \mathrm{g} \mathrm{ml}^{-1} \mathrm{BSA}\right)$, followed by 2 further washes at $47^{\circ} \mathrm{C}$ and immersion in $1 \times \mathrm{SSC}$ at $47^{\circ} \mathrm{C}$. Slides were blocked with $6 \%$ non-fat milk in Tris buffer ( $\mathrm{pH} 7.5$ ) before incubation with anti-DIG antibodies conjugated with alkaline phosphatase (Roche) in Tris pH 7.5 (1:300) for $1 \mathrm{~h}$ in darkness. Reactions were developed with $20 \mu \mathrm{ml}^{-1}$ nitroblue tetrazolium and 5-bromo-4-chloro-3-indoylphosphate (NBT/BCIP) (Roche) in Tris pH 9.5 until staining developed. Sections were then rinsed in Tris $\mathrm{pH} 9.5$ and counterstained with $0.5 \%$ Bismarck Brown Y in $30 \%$ ethanol, rinsed with tap water and dehydrated in IMS before they were coverslipped with Eukitt (Sigma). Sections were examined under light microscopy for the presence of haplosporidian stages.

\section{RESULTS}

\subsection{Histology and in situ hybridisation}

Haplosporidian plasmodia were observed by light microscopy in 6 out of 309 individual Mytilus edulis collected in the Tamar estuary. The same haplosporidian sequence type, Type 1, was amplified from all 6 individuals using a nested, haplosporidianspecific PCR. Haplosporidian plasmodia were observed associated with the gonadal tubules in the mantle, gill epithelium, vascular spaces and in the connective interstitial tissues of the digestive gland. In the mantle, unicellular stages were occasionally seen (Fig. 1A) occurring within the cytoplasm of the tubule epithelial cells. More frequently, larger multinucleate plasmodia containing several cells (up to approximately 12) were observed within the epithelium. In heavily infected tubules, the epithelium was disrupted or destroyed. Limited haemocyte infiltration with release of plasmodia into the lumen was seen in a few cases (Fig. 1B). Evidence of parasite division by cleavage and plasmotomy could be discerned (Fig. 1A,B,D) and migration of plasmodia through the epithelium of the gonadal tubule into the lumen was also detected (Fig. 1C). Gill infections were associated with the presence of numerous plasmodial stages within the respiratory epithelium and 


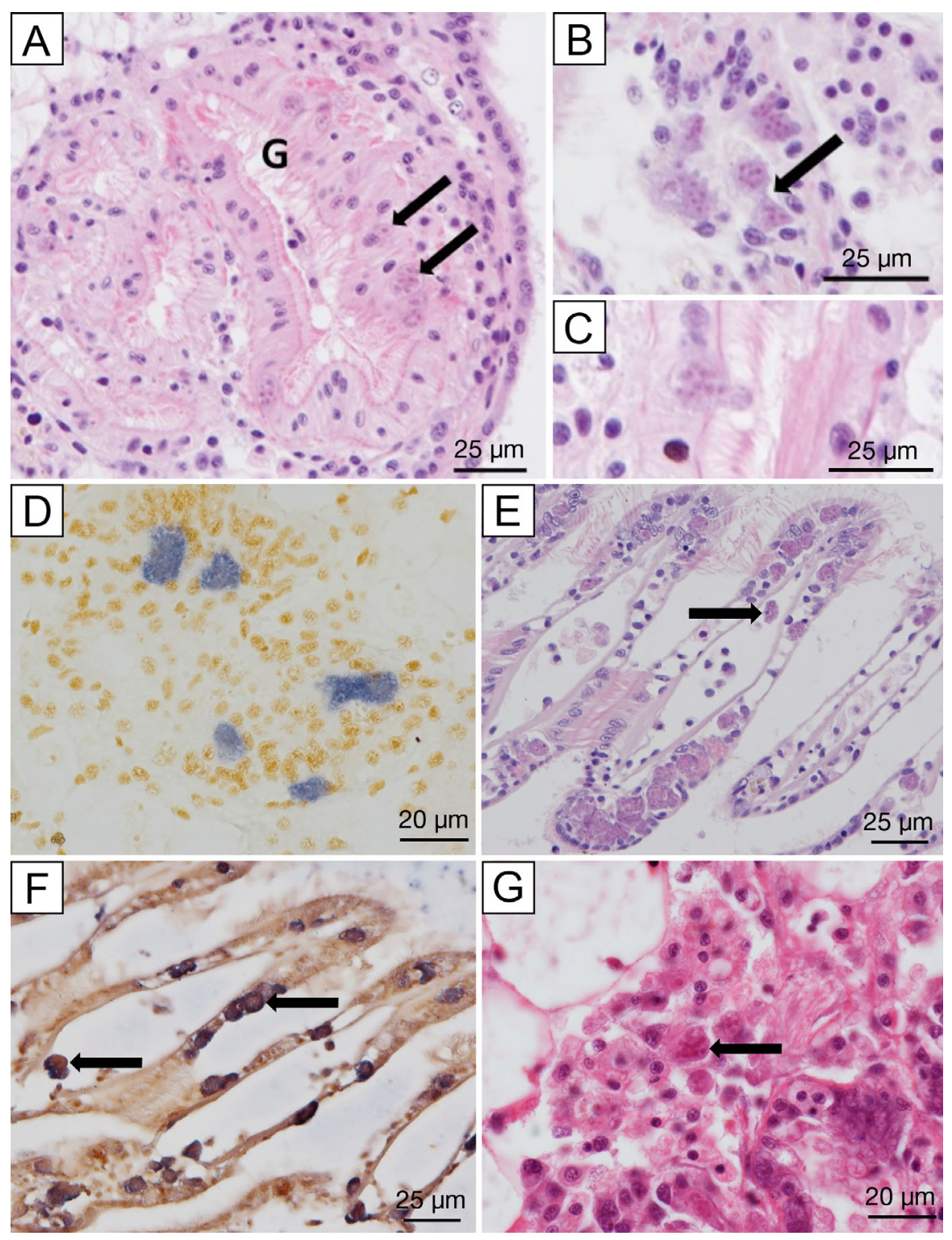

Fig. 1. Light micrographs showing Minchinia mytili cells in the gill, mantle and digestive gland tissues of host Mytilus edulis. (A) Section through several gonadal tubules (G) in the mantle of $M$. edulis, 2 of which contain unicellular stages and multinucleate intracellular plasmodia (arrows). (B) Plasmodial division by plasmotomy, each section containing several cells. (C) Migration of a single plasmodium through the epithelium of the gonadal tubule to the lumen. (D) Section from the same specimen as (B) showing labelling of plasmodia in a gonadal tubule. (E) Plasmodia within the gill epithelium with a few also present in the vascular space (arrow). (F) Same specimen as (E), showing specific labelling of haplosporidian plasmodia (arrows). (G) Interstitial tissue of the digestive gland with several plasmodia present (arrow). H\&E stain in (A-C, E, G); in situ hybridization labelling of plasmodial cytoplasm in $(\mathrm{E}, \mathrm{F})$

occasionally in the vascular spaces (Fig. 1E). No direct evidence of parasite migration through the epithelium was seen. Unlike infections in the gill and mantle, digestive gland infections were associated with mild haemocyte infiltration (Fig. 1G). TEM examination of digestive gland tissues from infected animals was unable to locate haplosporidian life stages for ultrastructural characterisation. ISH using the Type 1-specific probe bound to haplosporidian plasmodia in the mantle (Fig. 1D), gill (Fig. 1F) and digestive gland (not shown).

Of $40 \mathrm{M}$. edulis collected during the investigation of a mortality episode in farmed mussels on the west coast of Scotland, a severe haplosporidian infection was noted in a single specimen $(2.5 \%$ of sampled population). Numerous plasmodia were observed 
within the foot muscle, in the gills and throughout the connective tissue surrounding the digestive gland (Fig. 2). No sporulation stages were observed. Haemocytic infiltration and multifocal granulocytomas were observed in this individual and others sampled. Necrotic cells were present within the granulocytomas. DNA was extracted from formalin-fixed tissue from this individual, and subsequent PCR screens using haplosporidian-specific primer sets amplified a different $18 \mathrm{~S}$ sequence type than the samples from the Tamar estuary (Type 2).

A subset of PCR-positive mussels from the Tamar estuary from which the Type 2 sequence was amplified by a single-round (30 cycle) PCR were screened by ISH using a Type 2-specific probe. In each case no staining of plasmodia in any tissues was observed. Haplosporidian cells were also not observed in H\&Estained tissues, and so no microscopic evidence of this haplosporidian infecting $M$. edulis in the Tamar estuary was observed.

\subsection{PCR screening of tissues and environmental samples}

A summary of all nested and non-nested PCR screens of tissue and environmental samples is shown in Table 2. PCR screens of DNA extracted from the digestive gland tissues of $M$. edulis collected in the River Tamar estuary in June 2013 using general nested haplosporidian primers (Hartikainen et al. 2014a) produced an amplicon in 20 of 153 samples. Screening of DNA from digestive gland and mantle tissues from $M$. edulis collected at the same site in July 2013 produced amplicons in 63 of 156 and 12 of 156 samples respectively. In total, 11 of 56 mussels sampled produced amplicons from both tissues. Sanger sequencing of amplicons

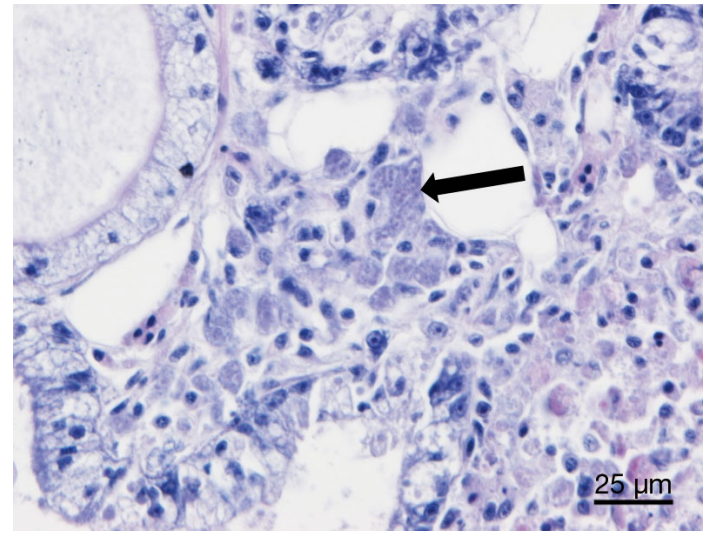

Fig. 2. Light micrograph showing several pleomorphic multinucleate haplosporidian plasmodia (arrow) in the interstitial tissue of the digestive gland of Mytilus edulis

from all mussels produced 2 distinct haplosporidian sequence types. Subsequent screens of the same sample sets using separate Type 1 and Type 2-specific primers in a single-round (30 cycle) PCR produced amplicons in 13 of 309 digestive gland and 7 of 156 mantle samples for Type 1, and 14 of 309 digestive gland and 0 of 156 mantle samples for Type 2. Screening of $M$. edulis incubation filters (16 total; June data set only) with 'Type'-specific primer pairs resulted in 8 positives from the Type 1 primers when nested with the first round primers of Hartikainen et al. (2014a) and 6 positives when the same primers were used as a single round, 30-cycle PCR. The Type 2 primers produced no positives as either a nested or a single-round PCR. Screens of filtered water samples collected at 3 sites within the Tamar estuary in June 2013 using the same primer sets and nested and non-nested strategies resulted in amplification from all sites by both primer sets.

Table 2. Prevalence of haplosporidian sequence types in Mytilus edulis digestive gland and mantle tissues by haplosporidiantargeted nested, and specific single-round PCR. Numbers in brackets following sample type indicate total number of samples screened. For nested PCR, a total of 60 cycles of amplification were used (30 each in first and second round); for non-nested PCRs, 30 amplification cycles were used

\begin{tabular}{|c|c|c|c|c|}
\hline \multirow[t]{2}{*}{ Dataset } & \multicolumn{2}{|c|}{ Minchinia mytili (Type 1) } & \multicolumn{2}{|c|}{ Haplosporidium sp. (Type 2) } \\
\hline & Nested & Specific & Nested & Specific \\
\hline June 2013 digestive gland only (153) & 9 & 5 & 11 & 2 \\
\hline July 2013 digestive gland (156) & 22 & 8 & 41 & 12 \\
\hline July 2013 mantle (156) & 13 & 7 & 2 & 0 \\
\hline M. edulis incubation filters (June dataset only) (16) & 8 & 6 & 0 & 0 \\
\hline Cremyll water column (6) & 1 & 1 & 6 & 4 \\
\hline Wilcove water column (14) & 5 & 3 & 11 & 6 \\
\hline Neal Point water column (18) & 2 & 0 & 17 & 9 \\
\hline
\end{tabular}




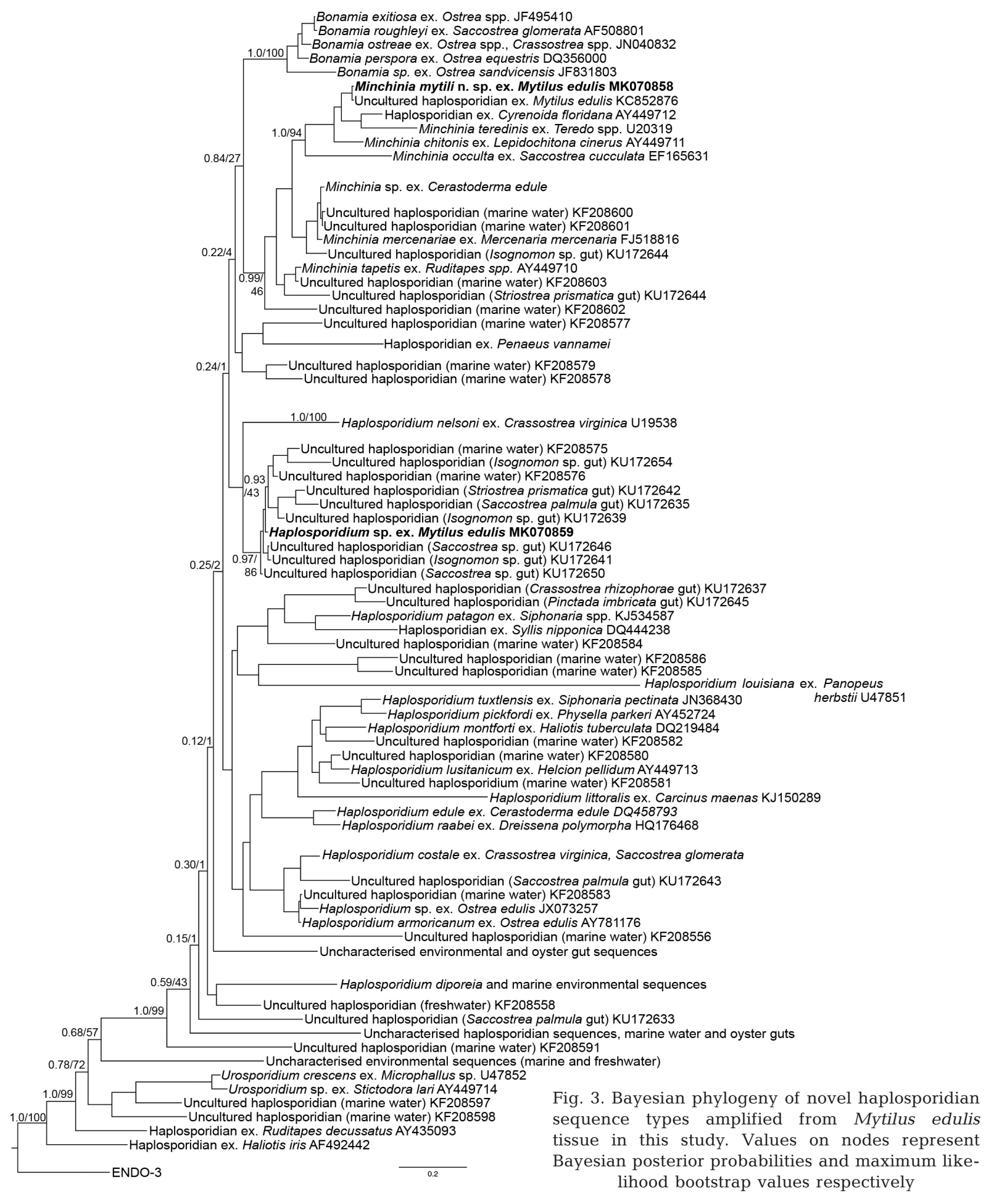

\subsection{Phylogenetic analyses}

Phylogenetic analyses including both nearly fulllength 18S haplosporidian sequences with all available haplosporidian 18S rRNA sequence types places Type 1 in a strongly supported monophyletic clade comprising all known Minchinia spp. plus related environmental sequences (Fig. 3). As expected from initial BLAST searches of the partial sequence, the closest relative of Type 1 is a previously uncharacterised haplosporidian sequence type derived from mussel tissue collected in the Menai Strait, Wales, UK. 
Type 2 falls within a group of uncharacterised sequences from marine water column and tropical oyster gut samples, sister to the oyster parasite Haplosporidium nelsoni, with strong support. As in previous studies, branches described as Haplosporidium and their relatives do not form a monophyletic clade.

\subsection{Taxonomic summary: Minchinia mytili n. sp.}

Specific diagnosis: Plasmodia associated with the gonadal tubes in the mantle, gill epithelium, vascular spaces and in the connective interstitial tissues of the digestive gland. Unicellular stages occasionally present within the cytoplasm of the tubule epithelial cells of the mantle. This species is distinguishable from all other haplosporidians by its unique 18S rRNA gene sequence, which can be specifically amplified by the diagnostic PCR using primers Hap-M258f/Hap-M412r or the in situ hybridisation probe generated by them.

Type host: Blue mussel Mytilus edulis

Type locality: Cremyll Ferry, Tamar estuary, Devon, United Kingdom (50² 21' 34.2" N, 4 10' 24.9" W)

Site of infection: Systemic, with plasmodia observed associated with the gonadal tubules in the mantle, gill epithelium, vascular spaces and in the connective interstitial tissues of the digestive gland.

Prevalence: Observed in 6 of 309 individuals examined histologically.

Etymology: The species epithet refers to its infection in the bivalve mollusc host Mytilus edulis

Type material: Reference tissue blocks (histology) and digoxigenin-stained in situ hybridisation slides and ethanol-fixed tissue are deposited in the Registry of Aquatic Pathology (RAP), held at the Centre for Environment, Fisheries and Aquaculture Science (Cefas), Weymouth, UK. Reference RA1308239

Gene sequence: The 18S rRNA gene sequence has the GenBank Accession Number MK070858

Zoobank registration: urn:lsid:zoobank.org:act:BC4 E1F46-FB74-48BB-B716-98054432BB2A

\section{DISCUSSION}

This study demonstrated the presence of 2 novel haplosporidian parasites infecting Mytilus edulis in the UK. The first of these, described here as Minchinia mytili, was observed infecting the gill, gonadal tubules and digestive connective tissues of mussels in the Tamar estuary, Devon, England. The second, which we informally refer to as Haplosporidium sp., was found infecting a single Mytilus edulis collected in Loch Spelve, Scotland.

Phylogenetic analyses place the Minchinia mytili 18S sequence type within the haplosporidian genus Minchinia with strong support, along with other parasites of molluscs including the bivalves Cyrenoida floridana (Minchinia sp.), Mercenaria mercenaria (Minchinia mercenariae) and Saccostrea cucculata (M. occulta). Though spore ornamentation is not available for this species, its infection of a molluscan host and strong phylogenetic placement within the genus is sufficient to describe this novel parasite as M. mytili.

The absence of sporogonic stages in all infected individuals examined is unusual for Minchinia spp., but it is not without precedent. The hard clam parasite $M$. mercenariae has recently been reported infecting cockles Cerastoderma edule in Galicia, Spain, with no observed sporogonic stages (Ramilo et al. 2018). As is true for $M$. mytili, M. mercenariae was present only at very low levels in the sampled cockle population, and so it is possible that in both cases too few infected individuals were available for examination with sufficiently advanced infection.

M. mytili infections were observed in the gill, mantle and digestive gland. Though no direct evidence of parasite migration through the gill epithelium was observed, the presence of haplosporidian plasmodia in the gills may indicate this tissue to be the route of entry into the host, as is the case for other ascetosporean parasites including Haplosporidium nelsoni (Lauckner 1983) and Marteilia spp. (Kleeman et al. 2002, Carrasco et al. 2008), with the eventual spread of proliferative (plasmodial) stages systemically through the host.

Another Minchinia species, M. occulta, infects the gill, mantle, reproductive follicles and digestive diverticulae of the rock oyster Saccostrea cuccullata. Sporulation has been observed only in the connective tissues of the digestive gland (Bearham et al. 2008). Infection in this case is presumed to develop in the gills before disseminating to the mantle and then the digestive gland, which may also be the case for M. mytili. Only a single individual was examined where $M$. mytili infection had progressed to the digestive connective tissues. It may be that examination of more infected mussels will reveal sporulation of $M$. mytili within the bivalve host. However, it cannot be ruled out that $M$. mytili does not sporulate in Mytilus edulis, but does so outside of this host.

Lynch et al. (2014) amplified a haplosporidian sequence type identical to Minchinia mytili from the 
gill tissue of Mytilus edulis collected in the Menai Strait, Wales. Though 'unidentified organisms' were observed in the tissue of the mussel from which the sequence was amplified, they could not be identified as haplosporidian. However, given the presence of the same sequence type in mussels in the Menai Strait, it is likely the same parasite is present in both populations.

Comps \& Tigé (1997) reported a haplosporidian producing Minchinia-like spores infecting Mytilus galloprovincialis in the Thau lagoon, southern France. Infection was limited to the connective tissues surrounding the digestive tubules, with little information to describe plasmodial stages. More recently, Matozzo et al. (2018) observed sporocysts containing haplosporidian-like spores in the digestive gland, gonad and mantle of a single specimen of M. galloprovincialis collected in Porto Venere, Gulf of La Spezia, Italy. In this case infection was systemic, with necrosis and atrophy of the digestive tubule epithelium associated with granular haemocytes. In situ hybridization using a general haplosporidian probe confirmed the affiliation of this parasite with the order. While it is possible both reports are of the same parasite, no sequence data exist in either case to confirm this.

An undescribed haplosporidian observed by Figueras et al. (1991) infecting M. edulis in Maine, USA showed similarities to Minchinia mytili. This parasite was observed infecting the tips of the gills, mantle epithelium and digestive connective tissues. Only plasmodial stages were observed, with no spore stages present. As with other reports of haplosporidian parasites of Mytilus spp., no molecular data are available for this parasite, and so it is not possible to state with any certainty their relation to Minchinia mytili.

We observed a further novel haplosporidian, infecting the digestive connective tissues, foot muscle and gills of a single mussel collected in Loch Spelve, Scotland, during a mortality episode not attributed to the parasite. As with $M$. mytili, spores were not observed in any tissue. Haemocytic infiltration and multifocal granulocytomas were observed in the infected individual and others from the same batch, with necrotic cells present within the granulocytomas. However, scuticociliate, bacterial and other infections were observed within the population (including the haplosporidian-infected individual), which are more likely to be the cause of these pathologies than haplosporidian infection.

The novel sequence type associated with this parasite was amplified from mussel digestive gland tissues from the Tamar estuary, though no haplosporid- ian life stages were observed by light microscopy or ISH. Phylogenetic analyses place this parasite in a clade comprising uncharacterised sequence types amplified from water column samples and tropical bivalve guts, sister to oyster parasite $H$. nelsoni. This clade is sister to Bonamia + Minchinia, and so species assigned to the genus Haplosporidium are paraphyletic, as in previous studies (Burreson \& Reece 2006, Hartikainen et al. 2014a, Pagenkopp-Lohan et al. 2016).

The haplosporidian infecting this specimen differs greatly from the only Haplosporidium species described from mussels, $H$. tumefacientis (Taylor, 1965). Though no sequence data is available for this species, tumefactions observed in the kidney and digestive gland of Mytilus californianus infected with $H$. tumefacientis are absent in the specimen from Loch Spelve, and so they are unlikely to be the same species.

This parasite is distinct from other haplosporidians observed in mussels, and the sequence type associated with the parasite is also novel; however, we lack sufficient data to fully describe this species and so refer to it informally as Haplosporidium sp.

The haplosporidian sequence type associated with Haplosporidium sp. was amplified from 41 of 156 of mussels collected in the Tamar estuary in July 2013. Screening the same samples using type-specific primers in a single-round, 30-cycle PCR reduced this number to 12. No haplosporidian life stages were observed in any individual using light microscopy or ISH. Burreson (2008) drew attention to the misuse of PCR assays in molluscan disease diagnosis and rightly stated that PCR-based detection methods must be validated against established microscopic techniques such as histology and in situ hybridisation. As such, we have no irrefutable evidence of Haplosporidium sp. infecting Mytilus edulis in the Tamar estuary. PCR positives indicate only the presence of Haplosporidium sp. DNA and in this case may indicate passage of parasite cells or DNA through the gut tubules by filter feeding rather than established infection. Barber \& Ford (1992) noted the presence of ingested H. nelsoni spores by light microscopy in the digestive lumen of Crassostrea virginica collected in Delaware Bay, USA (mean frequency 0.5 spores section $^{-1}$ ). Their presence appeared to be negatively correlated with $H$. nelsoni infection, suggesting they were unable to directly infect the oyster. In the case of Haplosporidium sp. a single histology slide was read for each individual, so any ingested haplosporidian spores may not be readily apparent. PCR assays are more sensitive than light microscopy, and will also detect haplosporidian DNA from digested cells. This highlights the impor- 
tance of validating PCR data with complementary light microscopy and ISH when inferring infection in bivalves.

Both novel haplosporidian sequence types were amplified from water column samples collected at the sample site. This finding is not unexpected; Hartikainen et al. (2014a) detected a wide diversity of haplosporidian sequence types in water and sediment samples, including both characterised and novel lineages. Though haplosporidians have previously been detected in planktonic metazoans by PCR (e.g. Bonamia ostreae, Lynch et al. 2007; H. nelsoni, Messerman \& Bowden 2016), no complementary microscopy or ISH was carried out, and so it is not possible to say whether this is representative of actual infection or trophic interactions. Similarly, it remains to be established how long these molecular signals can persist in the water column. B. ostreae has been shown to survive at $15^{\circ} \mathrm{C}$ in laboratory tests for at least $1 \mathrm{wk}$ (Arzul et al. 2009); however, the effects of predation and other external environmental factors are as yet untested. Further investigation is needed to understand the significance of eDNA findings, for example determining ribosomal activity of haplosporidian sequence types in environmental samples (and therefore which lineages represent living, active cells), and elucidating the role of planktonic metazoans and other invertebrates in haplosporidian life-cycles.

Acknowledgements. G.M.W. was supported by a Natural Environment Research Council GW4+ Doctoral Training Programme PhD studentship held at Exeter University, UK, The Natural History Museum (NHM), UK and Centre for Environment, Fisheries and Aquaculture Science (Cefas), UK; the work was also supported by funding from the UK Department of Environment, Food and Rural Affairs (Defra) under contract FC1214 (to D.B.) and FB002A (to S.W.F.). This work was also partly supported by the EU EU-funded project VIVALDI ('Preventing and Mitigating Farmed Bivalve Diseases') (H2020 program, no. 678589) to S.W.F. and D.B. D.B. was additionally supported by a NERC Standard Research Grant (NE/H000887/1). We thank Kelly Bateman and Grant Stentiford (Cefas) and Suzanne Williams (NHM) for sample collection in the Tamar estuary, and the Marine Science Scotland Fish Health Inspectorate for sample collection in Loch Spelve. We also thank Rachel Foster at NHM for assistance with sampling processing.

\section{LITERATURE CITED}

Arzul I, Carnegie RB (2015) New perspective on the haplosporidian parasites of molluscs. J Invertebr Pathol 131: $32-42$

Arzul I, Gagnaire B, Bond C, Chollet B and others (2009) Effects of temperature and salinity on the survival of
Bonamia ostreae, a parasite infecting flat oysters Ostrea edulis. Dis Aquat Org 85:67-75

Barber RD, Ford SE (1992) Occurrence and significance of ingested haplosporidian spores in the eastern oyster, Crassostrea virginica (Gmelin, 1791). J Shellfish Res 11: 371-375

* Bass D, Chao EEY, Nikolaec S, Yabuki A and others (2009) Phylogeny of novel naked filose and reticulose Cercozoa: Granofilosea cl. n. and Proteomyxidea revised. Protist 160:75-109

* Bearham D, Spiers Z, Raidal SR, Jones JB, Nicholls PK (2008) Spore ornamentation of Minchinia occulta n. sp. (Haplosporidia) in rock oysters Saccostrea cuccullata (Born, 1778). Parasitology 135:1271-1280

*Bignell JP, Dodge MJ, Feist SW, Lyons B and others (2008) Mussel histopathology: effects of season, disease and species. Aquat Biol 2:1-15

* Burreson EM (2008) Misuse of PCR assay for diagnosis of mollusc protistan infections. Dis Aquat Org 80:81-83

* Burreson EM, Ford SE (2004) A review of recent information on the Haplosporidia, with special reference to Haplosporidium nelsoni (MSX disease). Aquat Living Resour 17:499-517

Burreson EM, Reece KS (2006) Spore ornamentation of Haplosporidium nelsoni and Haplosporidium costale (Haplosporidia), and incongruence of molecular phylogeny and spore ornamentation in the Haplosporidia. J Parasitol 92:1295-1301

* Carnegie RB, Burreson EM, Hine PM, Stokes NA, Audemard C, Bishop MJ, Peterson CH (2006) Bonamia perspora n. sp. (Haplosporidia), a parasite of the oyster Ostreola equestris, is the first Bonamia species known to produce spores. J Eukaryot Microbiol 53:232-245

Carrasco N, Arzul I, Berthe FCJ, Furones MD (2008) In situ hybridisation detection of initial infective stages of Marteilia refringens (Paramyxea) in its host Mytilus galloprovincialis. J Fish Dis 31:153-157

Cavalier-Smith T, Chao EEY (2003) Phylogeny and classification of Phylum Cercozoa (Protozoa). Protist 154: 341-358

* Comps M, Tigé G (1997) Fine structure of Minchinia sp., a haplosporidian infecting the mussel Mytilus galloprovincialis L. Syst Parasitol 38:45-50

Engelsma MY, Culloty SC, Lynch SA, Arzul I, Carnegie RB (2014) Bonamia parasites: a rapidly changing perspective on a genus of important mollusc pathogens. Dis Aquat Org 110:5-23

*FAO (2017) Fishery and aquaculture statistics: global aquaculture production 1950-2015 (FishStatJ). www.fao.org/ fishery/statistics/software/fishstatj/en

Figueras AJ, Jardon CF, Caldas JR (1991) Diseases and parasites of mussels (Mytilus edulis Linneaus 1758) from two sites on the east coast of the United States. J Shellfish Res 10:89-94

Ford SE, Haskin HH (1982) History and epizootiology of Haplosporidium nelsoni (MSX), an oyster pathogen in Delaware Bay, 1957-1980. J Invertebr Pathol 40: 118-141

Ford SE, Stokes NA, Burreson EM, Scarpa E, Carnegie RB, Kraeuter JN, Bushek D (2009) Minchinia mercenariae n. sp. (Haplosporidia) in the hard clam Mercenaria mercenaria: implications of a rare parasite in a commercially important host. J Eukaryot Microbiol 56:542-551

*Hartikainen H, Ashford OS, Berney C, Okamura B and others (2014a) Lineage-specific molecular probing reveals 
novel diversity and ecological partitioning of haplosporidians. ISME J 8:177-186

Hartikainen H, Stentiford GD, Bateman KS, Berney C and others (2014b) Mikrocytids are a broadly distributed and divergent radiation of parasites in aquatic invertebrates. Curr Biol 24:807-812

Katoh K, Standley DM (2013) MAFFT multiple sequence alignment software version 7 : improvements in performance and usability. Mol Biol Evol 30:772-780

Kimbrough KL, Johnson WE, Lauenstein GG, Christensen JD, Apeti DA (2008) An assessment of two decades of contaminant monitoring in the nation's coastal zone. NOAA Tech Memo NOS NCCOS 74

Kleeman SN, Adlard RD, Lester RJG (2002) Detection of the initial infective stages of the protozoan parasite Marteilia sydneyi in Saccostrea glomerata and their development through to sporogenesis. Int J Parasitol 32:767-784

Larsson JIR (1987) On Haplosporidium gammari, a parasite of the amphipod Rivulogammarus pulex, and its relationships with the phylum Ascetospora. J Invertebr Pathol 49:159-169

Lauckner G (1983) Diseases of Mollusca: Bivalvia. In: Kinne O (ed) Diseases of marine animals, Vol II: Introduction, Bivalvia to Scaphopoda. Biologische Anstalt Helgoland, Hamburg, p 477-961

Lynch SA, Armitage DV, Coughlan J, Mulcahy MF, Culloty SC (2007) Investigating the possible role of benthic macroinvertebrates and zooplankton in the life cycle of the haplosporidian Bonamia ostreae. Exp Parasitol 115: 359-368

Lynch SA, Morgan E, Carlsson J, Mackenzie C and others (2014) The health status of mussels Mytilus spp., in Ireland and Wales with the molecular identification of a previously undescribed haplosporidian. J Invertebr Pathol 118:59-65

Matozzo V, Ercolini C, Serracca L, Battistini R and others (2018) Assessing the health status of farmed mussels (Mytilus galloprovincialis) through histological, microbiological and biomarker analyses. J Invertebr Pathol 153: 165-179

Messerman NA, Bowden TJ (2016) Survey of potential reservoir species of the oyster parasite Multinucleate Sphere X (Haplosporidium nelsoni) in and around oyster farms in the Damariscotta River estuary, Maine. J Shellfish Res 35:851-856

Pagenkopp Lohan KM, Hill-Spanik KM, Torchin ME, Aguirre-Mecedo L, Fleischer RC, Ruiz GM (2016) Richness and distribution of tropical oyster parasites in two oceans. Parasitology 143:1119-1132

Editorial responsibility: Kimberly Reece, Gloucester Point, Virginia, USA
Perkins FO (2000) Phylum Haplosporidia Caullery \& Mesnil, 1899. In: Lee JJ, Leedale G, Bradbury P (eds) The illustrated guide to the Protozoa, $2^{\text {nd }}$ edn. Society of Protozoologists, Lawrence, KS, p 1329-1341

Powell EN, Klinck JM, Ford SE, Hofmann EE, Jordan SJ (1999) Modeling the MSX parasite in Eastern oyster (Crassostrea virginica) populations. III. Regional application and the problem of transmission. J Shellfish Res 18: $517-537$

Ramilo A, Abollo E, Villalba A, Carballal MJ (2018) A Minchinia mercenariae-like parasite infects cockles Cerastoderma edule in Galicia (NW Spain). J Fish Dis 41: 41-48

Robert R, Borel M, Pichot Y, Trut G (1991) Growth and mortality of the European oyster Ostrea edulis in the Bay of Arcachon (France). Aquat Living Resour 4:265-274

* Ronquist F, Teslenko M, van der Mark P, Ayres DL and others (2012) MrBayes 3.2: efficient Bayesian phylogenetic inference and model choice across a large model space. Syst Biol 61:539-542

Sprague V (1972) Creation of a new genus and a new family in the Microsporidia. J Invertebr Pathol 20:228-231

Stamatakis A (2014) RAxML version 8: a tool for phylogenetic analysis and post-analysis of large phylogenies. Bioinformatics 30:1312-1313

Stamatakis A, Hoover P, Rougemont J (2008) A rapid bootstrap algorithm for the RaxML web servers. Syst Biol 57: 758-771

Stephenson MF, McGladdery SE (2002) Detection of a previously undescribed haplosporidian-like infection of a blue mussel (Mytilus edulis) in Atlantic Canada. J Shellfish Res 21:389 (Abstract)

Taylor RL (1966) Haplosporidium tumefacientis sp. n., the etiologic agent of a disease of the California sea mussel, Mytilus californiensis Conrad. J Invertebr Pathol 8: 109-121

Villalba A, Mourelle SG, Carballal MJ, López C (1997) Symbionts and diseases of farmed mussels Mytilus galloprovincialis throughout the culture process in the Rías of Galicia (NW Spain). Dis Aquat Org 31:127-139

* Ward GM, Bennett M, Bateman KS, Stentiford GD and others (2016) A new phylogeny and environmental DNA insight into paramyxids: an increasingly important but enigmatic clade of protistan parasites of marine invertebrates. Int J Parasitol 46:605-619

*Ward GM, Neuhauser S, Groben R, Ciaghi S, Berney C, Romac S, Bass D (2018) Environmental sequencing fills the gap between parasitic haplosporidians and freeliving giant amoebae. J Eukaryot Microbiol 65:574-586

Submitted: March 22, 2018; Accepted: November 27, 2018 Proofs received from author(s): February 4, 2019 